\begin{tabular}{|c|c|}
\hline 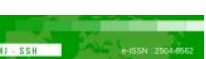 & Malaysian Journal of Social Sciences and Humanities (MJSSH) \\
\hline Malaysian Journal of & Volume 6, Issue 10, October 2021 \\
\hline (MJ-SSH) & e-ISSN : 2504-8562 \\
\hline & $\begin{array}{l}\text { Journal home page: } \\
\text { www.msocialsciences.com }\end{array}$ \\
\hline
\end{tabular}

\title{
Bimbingan Terancang dalam Kaedah Penyempurnaan Kuasa Dua Menggunakan Formula Verteks
}

\author{
Zetty Khairunisa Khali ${ }^{1}$, Roslinda Rosli ${ }^{1}$ \\ 1Fakulti Pendidikan, Universiti Kebangsaan Malaysia (UKM), Malaysia \\ Correspondence: Zettu Khairunisa Khali (p105211@siswa.ukm.edu.my)
}

\begin{abstract}
Abstrak
Fungsi kuadratik merupakan topik wajib yang perlu dipelajari oleh pelajar menengah atas terutama dalam mata pelajaran Matematik Tambahan. Kaedah penyempurnaan kuasa dua merupakan satu kaedah yang digunakan untuk menukar am bentuk fungsi kuadratik kepada bentuk verteks. Kaedah ini juga digunakan untuk menyelesaikan persamaan kuadratik. Bagaimanapun, pelajar sering melakukan kesilapan dalam menggunakan kaedah ini. Maka, kajian ini dijalankan untuk mengenal pasti kesilapan pelajar dalam menggunakan kaedah penyempurnaan kuasa dua dan merangka kaedah dan strategi pemulihan melalui sesi bimbingan terancang. Kajian ini telah dijalankan di sebuah sekolah di daerah Muar, Johor melibatkan seorang pelajar yang dikenal pasti bermasalah dalam mata pelajaran Matematik Tambahan tetapi menunjukkan potensi yang baik. Ujian diagnostik mendapati pelajar tidak dapat menggunakan kaedah penyempurnaan kuasa dengan betul. Maka, satu bimbingan terancang telah dijalankan dengan memfokuskan kepada penggunaan formula verteks dan seterusnya melihat bagaimana formula ini dapat membantu meningkatkan pemahaman pelajar dalam kaedah penyempurnaan kuasa dua.
\end{abstract}

Kata kunci: kaedah penyempurnaan kuasa dua, fungsi kuadratik, bimbingan terancang, formula verteks

\section{A Personal Tutoring in Completing the Square Method Using Vertex Formula}

\begin{abstract}
The quadratic function is a compulsory topic that needs to be studied by upper secondary students especially in the subject of Additional Mathematics. Completing the square method is a method used to convert the general form of a quadratic function to the vertex form. This method is also used to solve quadratic equation. However, students often make mistakes in using this method. Thus, this study was conducted to identify students' errors in using the squares completion method and devise remedial methods and strategies through personal tutoring sessions. The study was conducted in a school in Muar, Johor, involving a student who was identified as having problems in the subject of Additional Mathematics but showed good potential. The diagnostic tests found that students was unable to use the completing the square method correctly. Thus, a special tutoring was conducted with a focus on the use of vertex formulas and then to look at how this formula can help students' understanding in completing the square method.
\end{abstract}

Keywords: completing the square method, quadratic function, personal tutoring, vertex formula 


\section{Pengenalan}

Matematik Tambahan merupakan mata pelajaran elektif yang perlu dipelajari oleh pelajar yang mengambil pakej STEM semasa di menengah atas. Topik-topik dalam mata pelajaran ini dibahagikan kepada lima bidang iaitu Algebra, Geometri, Kalkulus, Trigonometri dan Statistik dan disusun dalam unit-unit kecil yang lengkap dan berasaskan pendekatan modular (Bahagian Pembangunan Kurikulum, 2018). Penukaran bentuk am fungsi kuadratik kepada bentuk verteks merupakan unit yang terkandung dalam bab 2 Fungsi Kuadratik Matematik Tambahan Tingkatan 4 di bawah bidang Algebra. Algebra merupakan salah satu bidang matematik yang mentafsirkan makna dan tujuan dengan menggunakan pemboleh ubah dan menjadi komponen utama matematik yang meluas digunakan dalam disiplin matematik lain seperti aritmetik, geometri, statistik dan kalkulus (Saundarajan et al., 2020). Pemikiran dan pengetahuan algebra sangat penting dalam mentafsirkan masalah di sekeliling secara matematik untuk mencari jalan penyelesaian (Ling et al., 2019). Menurut Celik dan Guzel (2017), kefahaman terhadap fungsi memerlukan pemikiran matematik dengan proses penaakulan yang tinggi berasaskan idea dan pemetaan yang pelbagai. Pembelajaran fungsi berkaitan dengan fungsi linear dan fungsi kuadratik yang mana fungsi kuadratik adalah lanjutan daripada fungsi linear dengan darjah yang lebih tinggi. Oleh itu, guru perlu mempertimbangkan pengajaran fungsi kuadratik mengikut kemampuan pelajar kerana kegagalan pelajar menghubungkan fungsi linear dengan fungsi kuadratik akan menyebabkan kesukaran kepada pelajar.

\section{Sorotan Literatur}

Kajian oleh Fachrudin et al. (2014) telah membuktikan bahawa penggunaan bahan geomeri dalam pengajaran algebra dapat membantu meningkatkan kefahaman pelajar terhadap penyelesaian persamaan kuadratik. Maat dan Zakaria (2014) pula menunjukkan bahawa kemahiran pelajar dalam menjawab soalan algebra adalah bergantung kepada pengetahuan guru dalam fungsi dan persamaan algebra. Dalam persamaan kuadratik, penyempurnaan kuasa dua merupakan kaedah yang digunakan untuk menyelesaikan persamaan yang sukar difaktorkan (Alhassan \& Agyei, 2020). Maka, beliau menyatakan bahawa penggunaan kaedah penyempurnaan kuasa dua adalah lebih tepat dan pantas dalam menyelesaikan persamaan kuadratik.

Dalam fungsi kuadratik pula, penukaran bentuk ini akan membantu pelajar menterjemahkan graf kuadratik. Kesilapan pelajar menukar bentuk am fungsi kuadratik kepada bentuk verteks akan menyebabkan kesilapan dalam menentukan persamaan paksi simetri, nilai maksimum atau nilai minimum, menentukan koordinat titik pusingan dan seterusnya kesilapan dalam melakar graf. Malah, Hendel (2017) turut menggariskan kepentingan parameter dalam fungsi kuadratik iaitu bentuk verteks, bentuk punca, bentuk am dan bentuk kadar. Parameter ini membantu pelajar dalam menterjemahkan persamaan dan fungsi kuadratik dalam situasi soalan yang berbeza. Oleh kerana kepentingan penukaran bentuk am fungsi kuadratik kepada bentuk verteks ini, maka bimbingan terancang ini akan memfokuskan kepada kaedah penyempurnaan kuasa dua menggunakan formula verteks.

\section{Tujuan Kajian}

Bimbingan terancang ini bertujuan untuk menganalisis kesalahan pelajar dalam menggunakan kaedah penyempurnaan kuasa dua dan menukar bentuk am fungsi kuadratik kepada bentuk verteks menggunakan formula verteks. Seterusnya, daripada analisis kesalahan ini pelajar akan dibimbing secara peribadi menggunakan formula ini. Berdasarkan tujuan kajian ini, beberapa objektif kajian telah dibentuk iaitu:

i. Mengenal pasti kesilapan pelajar dalam menukar bentuk am fungsi kuadratik kepada bentuk verteks.

ii. Mengenal pasti kesilapan pelajar dalam menggunakan kaedah penyempurnaan kuasa dua.

iii. Merangka kaedah dan strategi pemulihan melalui sesi bimbingan. 


\section{Metod Kajian}

Kajian ini menggunakan pendekatan kualitatif melibatkan lima fasa iaitu ujian diagnostik, temu bual, sesi bimbingan, ujian penilaian dan refleksi. Ujian diagnostik bertujuan untuk mendapatkan maklumat terhadap pemikiran pelajar, melihat kaedah menjawab pelajar dan menganalisis kesilapan yang dilakukan oleh pelajar. Maklumat ini akan digunakan untuk merangka strategi dan kaedah mengatasi kesilapan yang dilakukan oleh pelajar semasa sesi bimbingan. Ujian penilaian akan melihat sejauh mana sesi bimbingan dapat membantu pelajar mengurangkan kesilapan menjawab. Latihan tambahan diberikan kepada pelajar dengan tujuan untuk membantu mengukuhkan kebolehan pelajar menjawab soalan manakala ujian penilaian dijalankan dengan konsep soalan yang berbeza bagi melihat proses kognitif pelajar terhadap maklumat yang disampaikan semasa sesi bimbingan. Semua fasa ini akan digunakan untuk membuat kesimpulan terhadap kajian ini.

\section{Peserta Kajian}

Seorang pelajar Tingkatan 5 di sebuah sekolah menengah di Muar, Johor telah dipilih berdasarkan tahap pembelajaran dan pencapaian pelajar ini dalam mata pelajaran Matematik Tambahan. Pelajar ini menunjukkan pencapaian yang agak rendah tetapi berpotensi dalam menyumbang kecemerlangan dalam Matematik Tambahan SPM 2021. Pelajar telah dimaklumkan terlebih dahulu tentang sesi bimbingan dan pelajar menyatakan persetujuan.

\section{Pengumpulan Data}

Data kajian ini diperoleh daripada ujian diagnostik, temu bual, sesi personal, latihan tambahan dan ujian penilaian. Analisis ujian diagnostik, latihan tambahan dan ujian penilaian menggunakan kaedah analisis dokumen yang memerlukan data diperiksa dan ditafsirkan. Jawapan pelajar dalam ketiga-tiga ujian ini akan disemak dan dianalisis manakala sesi temu bual akan dirakam secara digital. Keseluruhan sesi bimbingan ini akan diperhatikan dan kesimpulan akan dibuat berdasarkan dapatan kajian.

Rajah 1: Proses pengumpulan data

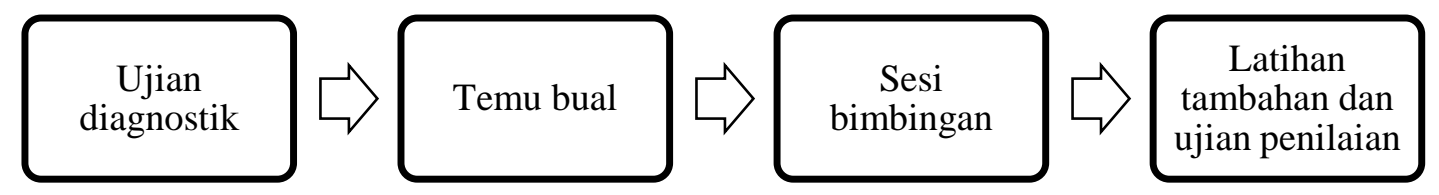

\section{Rancangan Pengajaran}

\begin{tabular}{ll}
\hline Item & Butiran \\
\hline Tarikh/Hari & 14 April 2021 (Rabu) \\
Masa & 2.15 petang -2.45 petang (30 minit) \\
Tajuk & Fungsi Kuadratik \\
Bidang & Algebra \\
Standard & Membuat perkaitan antara bentuk verteks fungsi kuadratik, $f(x)=$ \\
Pembelajaran & $a(x-h)^{2}+k$ dengan bentuk fungsi kuadratik yang lain. \\
Objektif & $\begin{array}{l}\text { Menukar bentuk am fungsi kuadratik kepada bentuk verteks menggunakan } \\
\text { kaedah penyempurnaan kuasa dua dan formula verteks. }\end{array}$ \\
Bahan Bantu Belajar & Kertas soalan, kalkulator \\
Aktiviti & 1. Guru menerangkan semula konsep penyempurnaan kuasa dua \\
& kepada pelajar seperti yang telah dipelajari dalam sub topik \\
& Penyelesaian Persamaan Kuadratik. \\
& 2. Pelajar ditunjukkan kaedah menukar bentuk am fungsi kuadratik \\
& kepada bentuk verteks dengan menggunakan kaedah \\
penyempurnaan kuasa dua.
\end{tabular}


3. Pelajar diterangkan juga aplikasi kaedah penyempurnaan kuasa dua dalam fungsi kuadratik.

4. Pelajar ditunjukkan kaedah alternatif menukar bentuk dengan menggunakan formula verteks.

5. Pelajar diberikan contoh yang memerlukan pelajar menggunakan kedua-dua kaedah.

6. Pelajar diberikan latihan tambahan.

7. Guru menanda latihan pelajar dan membincangkan jawapan tersebut jika terdapat kesilapan yang dilakukan oleh pelajar.

\section{Dapatan Kajian}

Dapatan kajian diperoleh daripada ujian diagnostik, temu bual, sesi bimbingan, latihan tambahan dan ujian penilaian. Sesi bimbingan ini telah melibatkan seorang pelajar Tingkatan 5 di sebuah sekolah menengah di Muar. Pelajar tersebut telah diberikan maklumat terlebih dahulu berkaitan sesi bimbingan ini yang bertujuan untuk membantu pelajar menjawab soalan menukar bentuk am persamaan kuadratik kepada bentuk penyempurnaan kuasa dua dengan menggunakan formula verteks. Pelajar dipilih berdasarkan tahap penguasaan yang agak lemah dalam mata pelajaran Matematik Tambahan terutama dalam sub topik ini.

\section{Ujian Diagnostik}

Pada awal pertemuan, pelajar telah diberikan ujian diagnostik dengan tujuan untuk menganalisis kesalahan yang dilakukan ketika menukar bentuk am fungsi kuadratik kepada bentuk verteks dengan menggunakan kaedah penyempurnaan kuasa dua. Pelajar diberikan masa 30 minit untuk menjawab empat soalan tanpa sebarang bimbingan. Sepanjang proses menjawab, pelajar memberikan reaksi yang tidak selesa terhadap soalan dan menunjukkan ketidakyakinan dalam menjawab soalan. Keempat-empat soalan disediakan dengan menggunakan bentuk yang sama tetapi berbeza daripada segi nilai pemalar $a$ yang terdapat dalam bentuk am fungsi kuadratik. Perbezaan nilai $a$ yang berbeza ini dapat menganalisis kesilapan pelajar dalam konteks yang berbeza.

Rajah 2: Contoh kesalahan pelajar

\begin{tabular}{|l|r|}
\hline$f(x)=x^{2}+4 x-9$ & $f(x)=-x^{2}-6 x+9$ \\
$f(x)=x^{2}+4 x-9$ & \\
$f(x)=\left(x^{2}+\frac{4}{2} \otimes\right)-\left(\frac{4}{2} \otimes\right)-9$ & $f(x)=-x^{2}-6 x+9$ \\
$=\left(x^{2}+2 x\right)-(2 x)-9$ & $=\left(-x^{2}-\frac{6}{2} \otimes\right)-\left(\frac{6}{2} \otimes\right)+9$ \\
$=-2 x^{3}-4 x^{2}+18 x$ & $=3 x^{3}+9 x^{2}-27 x$
\end{tabular}

Dalam kaedah penyempurnaan kuasa dua, nilai $a \neq 1$ memerlukan kemahiran pemfaktoran oleh pelajar dan di sini pelajar diuji dengan konsep asas matematik. Perbezaan soalan juga dapat menguji kemahiran pelajar dalam memahami syarat kaedah penyempurnaan kuasa dua. Daripada ujian diagnostik ini didapati pelajar membuat kesilapan yang sama dengan mengabaikan nilai pemalar $a$ dan tidak mahir tentang bentuk verteks yang menyebabkan kesilapan dalam menggunakan formula. Sebelum menukar bentuk am kepada bentuk verteks, pelajar perlu memastikan bahawa nilai pemalar $a=1$. Merujuk kepada soalan kedua, pelajar perlu menukar fungsi kuadratik ini kepada $f(x)=-\left(x^{2}+6 x-9\right)$ terlebih dahulu bagi 
memenuhi syarat $a=1$. Maka, kesilapan pelajar di sini ialah tidak memfaktorkan fungsi kuadratik ini terlebih dahulu.

\section{Sesi Temu Bual}

Selepas pelajar selesai menjawab soalan diagnostik, satu sesi temu bual telah dijalankan bagi mengetahui gaya pembelajaran pelajar dalam Matematik Tambahan. Berikut ialah temu bual tersebut:

$\begin{array}{ll}\text { Penemu bual } & \text { : Macam mana cara awak belajar di rumah? } \\ \text { Pelajar } & \text { :Ada belajar sikit-sikit. } \\ \text { Penemu bual } & \text { :Ada buku latihan? } \\ \text { Pelajar } & \text { : Ada. Ada beli melalui sekolah. Buat dalam buku iu. } \\ \text { Penemu bual } & \text { : Ada bertanya dengan guru kalau tak faham? } \\ \text { Pelajar } & \text { :Ada. Tanya kat Whatsapp. } \\ \text { Penemu bual } & \text { : Ada sesiapa di rumah yang boleh bantu awak kalau tak faham? } \\ \text { Pelajar } & \text { :Takda. Saya belajar sendiri. Kadang tanya kawan, kadang tanya cikgu. } \\ \text { Penemu bual } & \text { : Setakat ni rasa seronok dengan Matematik Tambahan? } \\ \text { Pelajar } & \text { : Saya suka. Cuma susah sikit. Tapi saya suka. }\end{array}$

Jawapan pelajar menunjukkan pelajar tiada rakan belajar yang boleh membantu pelajar di luar waktu sekolah. Pelajar juga tidak membeli sebarang buku latihan atau rujukan lain, hanya bergantung kepada pihak sekolah yang menyediakan buku atau modul. Faktor persekitaran, keluarga dan sosioekonomi memberi kesan kepada gaya pembelajaran pelajar dan menjadi salah satu punca kepada kelemahan dalam mata pelajaran Matematik Tambahan. Bagaimanapun, pelajar menunjukkan semangat dan minat untuk belajar dan ini menunjukkan motivasi pelajar masih ada walaupun di tahap yang rendah. Pelajar masih boleh dibimbing dan berpotensi menyumbang kecemerlangan akademik di sekolah.

\section{Sesi Bimbingan}

Pelajar telah diberi rehat selama 15 minit selepas sesi temu bual sebelum disambung dengan sesi bimbingan. Sesi ini telah berjalan selama 30 minit berpandukan kepada rancangan mengajar yang telah dibina. Pengajaran berpusatkan guru telah dilaksanakan dalam sesi bimbingan ini. Pelajar diberikan bimbingan dengan menyatakan konsep utama dalam kaedah penyempurnaan kuasa dua. Rancangan pengajaran ini membantu guru dalam menstrukturkan sesi bimbingan agar berjalan lancar. Dalam sesi ini, kesilapan yang dilakukan oleh pelajar dalam ujian diagnostik telah dibincangkan bersama-sama. Pelajar telah ditunjukkan kesilapan yang telah dilakukan dan diajar semula cara menukar bentuk am fungsi kuadratik kepada bentuk verteks dengan menggunakan kaedah penyempurnaan kuasa dua. Sebagai alternatif, pelajar juga diajar menukar bentuk dengan menggunakan formula verteks.

Penggunaan kaedah penyempurnaan kuasa dua adalah kaedah piawai yang terkandung dalam buku teks Matematik Tambahan KSSM Tingkatan 4. Sepanjang sesi bimbingan, pelajar menunjukkan tindak balas yang baik dan pelajar juga diberi ruang untuk bertanyakan soalan. Dalam pemerhatian ringkas, kegagalan pelajar menggunakan kaedah penyempurnaan kuasa dua ialah kerana tidak mengingati jalan kerja dan tidak memahami konsep pemfaktoran yang menjadi asas dalam kaedah ini. Sedikit temu bual juga dijalankan semasa sesi bimbingan untuk melihat kefahaman pelajar terhadap kaedah penyempurnaan kuasa dua menggunakan formula verteks.

\section{Bimbingan Menggunakan Formula Verteks}

Fungsi kuadratik merupakan sukatan wajib yang perlu dipelajari oleh pelajar menengah atas. Fungsi kuadratik ialah fungsi polinomial dengan kuasa tertinggi 2 yang ditulis dalam bentuk am iaitu $f(x)=$ $a x^{2}+b x+c$ dengan keadaan $a, b$ dan $c$ adalah pemalar dan $a \neq 0$. Di peringkat sekolah menengah, adakalanya guru dan pelajar mewakilkan fungsi kuadratik dalam bentuk $y=a x^{2}+b x+c$ dan mereka juga akan kerap menemui bentuk $a x^{2}+b x+c=0$ yang merujuk kepada persamaan kuadratik (Nielsen, 2015). Bentuk am fungsi kuadratik boleh ditukarkan kepada bentuk verteks, $f(x)=$ 
$a(x-p)^{2}+q$ dengan menggunakan kaedah penyempurnaan kuasa dua. Kaedah tersebut ialah seperti berikut:

$$
\begin{gathered}
f(x)=a x^{2}+b x+c \\
f(x)=a\left(x+\frac{b}{2 a}\right)^{2}-\left(\frac{b}{2 a}\right)^{2}+\frac{c}{a}
\end{gathered}
$$

Merujuk formula di atas, maka, $p=-\frac{b}{2 a}$ dan $q=-\left(\frac{b}{2 a}\right)^{2}+\frac{c}{a}$. Nilai $p$ merujuk kepada persamaan paksi simetri manakala nilai $q$ merujuk kepada nilai maksimum atau nilai minimum. Gabungan nilai $(p, q)$ membentuk koordinat verteks. Fungsi kuadratik ini diwakilkan dalam bentuk graf dengan koordinat verteks yang terhasil. Penukaran bentuk am kepada bentuk verteks ini sangat penting kerana bentuk verteks dapat memberikan banyak maklumat berkaitan fungsi kuadratik. Daripada kaedah penyempurnaan kuasa dua ini, satu formula yang lebih mudah boleh digunakan pelajar iaitu seperti berikut:

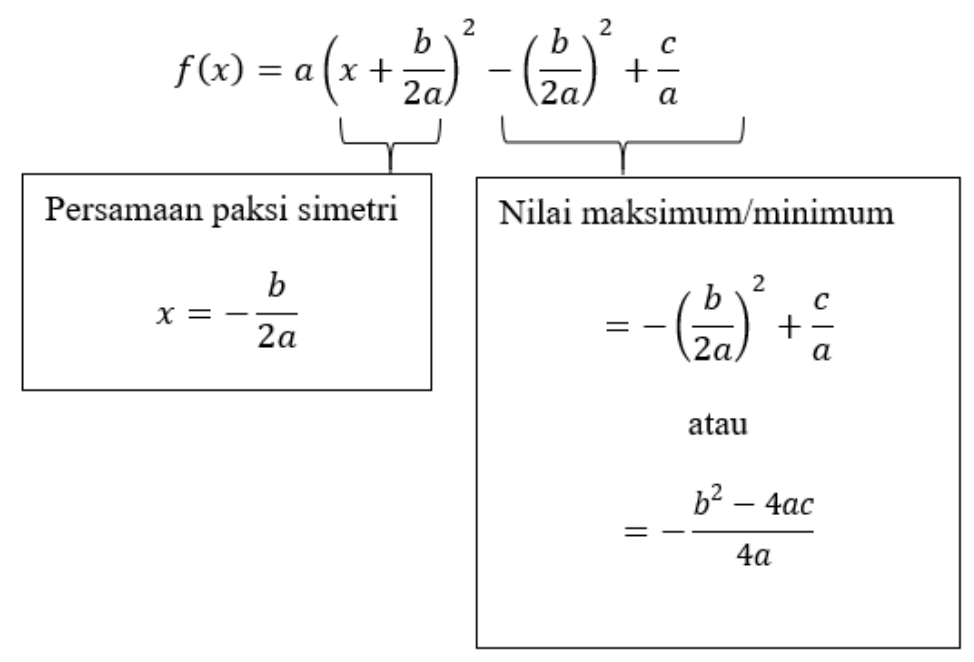

\section{Contoh 1:}

$$
f(x)=x^{2}-6 x-10
$$

Daripada fungsi ini, didapati $a=1, b=-6$ dan $c=-10$

$$
\begin{aligned}
& \left(x+\frac{b}{2 a}\right)^{2} \\
& q=-\frac{b^{2}-4 a c}{4 a} \\
& f(x)=a\left(x+\frac{b}{2 a}\right)^{2}+q \\
& =\left[x+\frac{-6}{2(1)}\right]^{2} \\
& q=-\frac{(-6)^{2}-4(1)(-10)}{4(1)} \\
& f(x)=(x-3)^{2}-19 \\
& =(x-3)^{2} \\
& q=-19
\end{aligned}
$$




\section{Contoh 2:}

$$
f(x)=-x^{2}-8 x+11
$$

Daripada fungsi ini, didapati $a=-1, b=-8$ dan $c=11$

$$
\begin{aligned}
& \left(x+\frac{b}{2 a}\right)^{2} \\
& q=-\frac{b^{2}-4 a c}{4 a} \\
& =\left[x+\frac{-8}{2(-1)}\right]^{2} \\
& q=-\frac{(-8)^{2}-4(-1)(11)}{4(-1)} \\
& f(x)=a\left(x+\frac{b}{2 a}\right)^{2}+q \\
& =(x+4)^{2} \\
& q=\mathbf{2 7} \\
& f(x)=-(x+4)^{2}+27
\end{aligned}
$$

Sesi bimbingan telah berjalan dalam tempoh 30 minit. Selain daripada menerangkan cara menukar bentuk am fungsi kuadratik kepada bentuk verteks, pelajar juga diterangkan dengan konsep asas fungsi kuadratik. Penggunaan dan tujuan penukaran bentuk ini juga diterangkan iaitu dengan tujuan melakar dan membina graf. Selain itu, bentuk verteks juga membantu pelajar untuk menentukan persamaan paksi simetri graf dan nilai maksimum serta nilai minimum. Untuk ujian pasca, pelajar dapat menjawab semua soalan dengan betul. Bagaimanapun apabila soalan penilaian diberikan bagi tujuan melihat penggunaan kaedah penyempurnaan kuasa dua dengan lebih menyeluruh, pelajar masih melakukan kesilapan. Semasa sesi bimbingan, pelajar juga ditanya tentang beberapa soalan berkaitan fungsi kuadratik dan kaedah penyempurnaan kuasa dua.
Репети bual
: Setakat ujian dan latihan yang dibuat hari ini, awak okay?
Pelajar $B$
: Okay cikgu. Saya dah ingat dah.
Peneтu bual
: Cuba awak nyatakan nilai $a, b$ dan $c$ dalam fungsi $f(x)=2 x^{2}-3 x+5$.
Pelajar A
$\therefore$ Saya ingat cikgu. $a=2, b=-3, c=5$. c tu pintasan-y.
Penemu bual
: Bagus. Jadi apa kesalahan yang awak nampak dalam ujian diagnostik tadi?
Pelajar C
: Saya ingat sikit kalau a $=1$. Kalau tak sama dengan 1 tu, lupa nak faktorkan.
Penemu bual
: Selain itu, ada masalah lain dalam kaedah penyempurnaan kuasa dua?
Pelajar A
: Bila nak turunkan nilai tu semua saya tak berapa ingat. Nak faktorkan pun lupa.
Penemu bual
: Perasan tak tadi kesalahan awak semuanya hampir sama?
Pelajar B
: Ya, tapi sekarang rasa dah ingat dah.
Penemu bual $\quad$ : Kita buat latihan tambahan sikit eh. Tadi salah semua. Yang ni awak cuba.
Pelajar C : Soalan sama?
Penemu bual : : Beza. Tapi bentuk sama.
Pelajar A : Okay.

Daripada temu bual ini, pelajar tiada masalah dalam menentukan nilai-nilai $a, b$ dan $c$ dalam bentuk am fungsi kuadratik. Pelajar faham tentang bentuk am persamaan kuadratik. Pelajar hanya tidak dapat mengingati dengan sempurna bagaimana kaedah penyempurnaan kuasa dua dijalankan. Ini menunjukkan asas pelajar yang lemah daripada pengetahuan sedia ada pelajar. Konsep pemfaktoran juga menjadi masalah kepada pelajar yang mana kesalahan dalam ujian diagnostik berpunca daripada kegagalan pelajar memfaktorkan fungsi kuadratik tersebut. Oleh itu, latihan tambahan diberi untuk menguji ingatan dan kefahaman pelajar dan seterusnya meningkatkan keyakinan pelajar terhadap sesi bimbingan yang dihadiri.

\section{Latihan Tambahan dan Ujian Penilaian}

Latihan tambahan mempunyai empat soalan yang mirip dengan ujian diagnostik. Ini bertujuan memberi peluang kepada pelajar menggunakan sepenuhnya pengetahuan yang diperoleh dalam sesi bimbingan. Pelajar tidak diberikan tempoh masa menjawab yang tertentu. Pemerhatian awal mendapati pelajar menjawab latihan tambahan dengan lebih tenang dan gembira. Dapatan daripada latihan tambahan ini menunjukkan pelajar dapat menjawab semua soalan dengan betul. Faktor soalan yang hampir sama dan jarak masa antara ujian diagnostik dan latihan tambahan ini menyumbang kepada ingatan, kefahaman dan kejayaan pelajar. Selepas latihan tambahan ini, pelajar diingatkan sekali lagi tentang kaedah 
penyempurnaan kuasa dua, syarat yang perlu dipatuhi dan maklumat lain yang berkaitan dengan bentuk verteks. Pelajar menunjukkan keyakinan yang tinggi selepas latihan tambahan ini. Bagi meningkatkan kadar kepercayaan terhadap keberkesanan sesi bimbingan ini, satu ujian penilaian diberikan kepada pelajar. Ujian penilaian ini mengandungi soalan yang sedikit berbeza berbanding ujian diagnostik dan latihan tambahan supaya kemampuan pelajar dapat diuji apabila melibatkan soalan yang berbeza bentuk walaupun menggunakan konsep yang sama.

Ujian penilaian telah dijalankan tiga hari selepas ujian diagnostik dan sesi bimbingan. Jarak masa ini memberi peluang kepada guru melihat tahap ingatan dan kefahaman pelajar. Soalan yang diberikan juga berbeza berbanding soalan ujian diagnostik dan ujian pasca. Ujian penilaian dijalankan dalam tempoh 30 minit yang menguji kefahaman dan daya ingatan pelajar terhadap kaedah penyempurnaan kuasa dua, bentuk am fungsi kuadratik dan bentuk verteks. Dapatan daripada ujian penilaian ini, pelajar dapat mengaplikasikan penggunaan kaedah penyempurnaan kuasa dua dalam menjawab soalan-soalan fungsi kuadratik. Bagaimanapun, pelajar masih melakukan kesalahan daripada segi pemfaktoran dan mentafsir maklumat. Jarak masa antara sesi bimbingan dengan ujian penilaian bertujuan untuk melihat daya ingatan jangka panjang dan kefahaman pelajar. Bentuk soalan yang berbeza berbanding soalan diagnostik dan latihan tambahan juga memberi kesan kepada pencapaian pelajar. Ini menunjukkan bahawa pelajar yang kerap membuat latihan dapat menunjukkan pencapaian yang memberangsangkan.

Rajah 3: Contoh jawapan pelajar dalam ujian penilaian

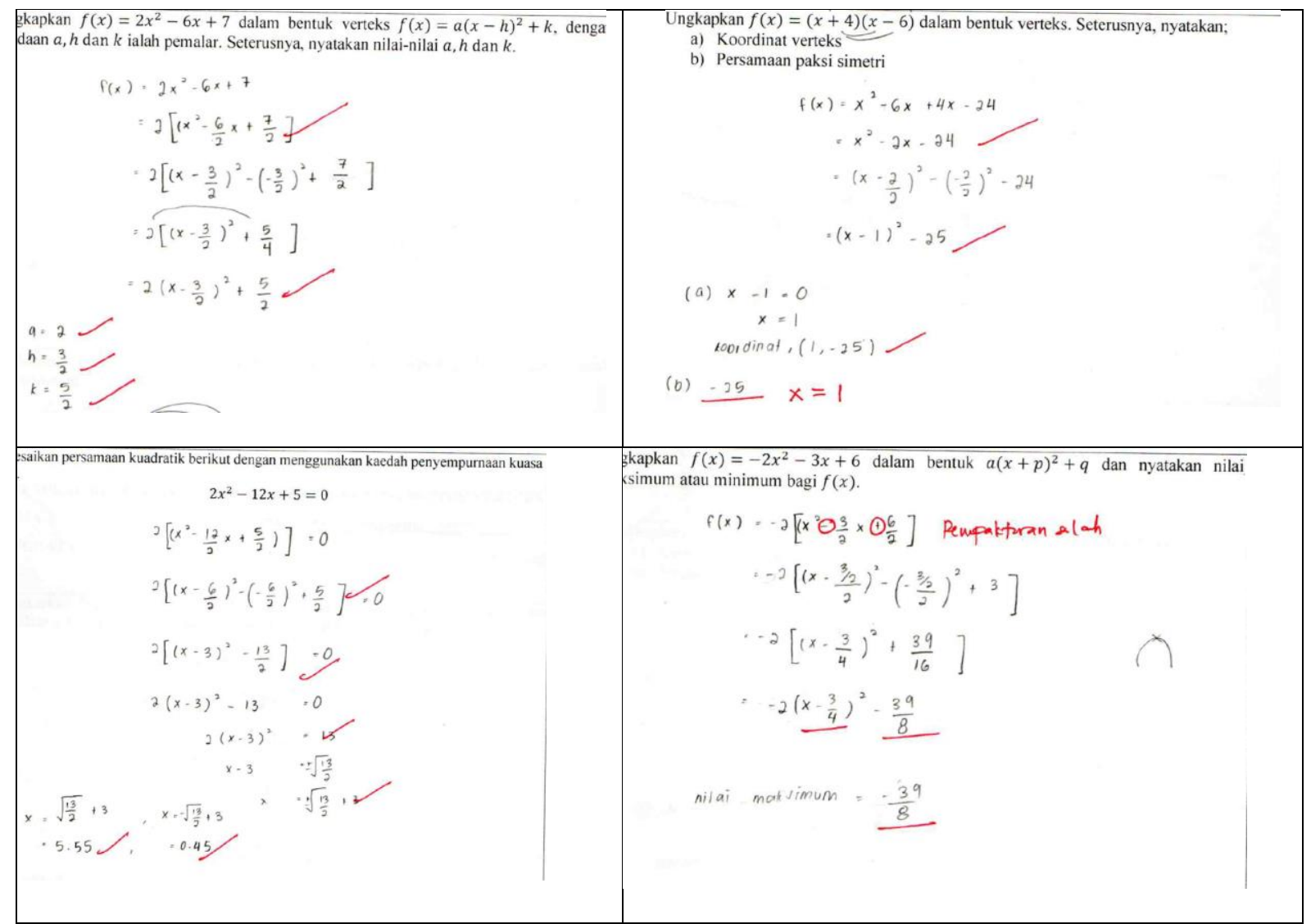

Walaupun masih terdapat kesilapan dalam beberapa soalan, hasil daripada bimbingan yang telah dijalankan menunjukkan keputusan ujian penilaian yang positif. Pelajar dapat melaksanakan kaedah penyempurnaan kuasa dua dengan betul. Pelajar juga tahu syarat asas kaedah penyempurnaan kuasa dua adalah $a=1$ yang memerlukan pelajar membuat pemfaktoran terlebih dahulu. Pelajar juga dapat menentukan nilai $a, h$ dan $k$ dengan betul. 


\section{Perbincangan}

Tiga sesi menjawab soalan telah dilaksanakan dalam kajian ini iaitu ujian diagnostik dan latihan tambahan yang menggunakan bentuk soalan yang sama dan ujian penilaian yang menggunakan bentuk soalan yang berbeza. Latihan tambahan menunjukkan perubahan cara menjawab yang ketara daripada pelajar berbanding ujian diagnostik. Pelajar dapat menjawab semua soalan dengan betul dan tepat. Bagaimanapun, dalam ujian penilaian masih terdapat kesalahan kecil yang dilakukan oleh pelajar. Antara kesalahan pelajar ialah;

1. Kesalahan dalam menukar bentuk am fungsi kuadratik kepada bentuk verteks adalah pada soalan dengan nilai $a=2$. Syarat am dalam penukaran bentuk ini ialah $a=1$. Jika $a$ bernilai selain daripada 1, maka pelajar perlu membuat pemfaktoran terlebih dahulu dan kemudian mengembangkannya semula setelah selesai proses penyempurnaan kuasa dua.

2. Pelajar tidak mahir menggunakan kaedah formula yang lebih mudah untuk menukar bentuk am fungsi kuadratik kepada bentuk verteks tetapi pelajar tahu bahawa persamaan paksi simetri atau nilai $x=-\frac{b}{2 a}$.

Bagaimanapun, daripada bimbingan ini, formula verteks dikenal pasti boleh digunakan untuk membantu pelajar menukar bentuk fungsi kuadratik kepada bentuk penyempurnaan kuasa dua dengan lebih mudah. Penggunaan verteks dapat mengurangkan kesalahan pelajar dan membantu pelajar dalam situasi berikut:

1. Apabila fungsi kuadratik $f(x)=a x^{2}+b x+c$ dengan keadaan $a \neq 1$.

2. Apabila soalan memerlukan persamaan paksi simetri bagi suatu graf fungsi kuadratik, maka pelajar boleh terus menggunakan formula $x=-\frac{b}{2 a}$.

3. Apabila soalan mengehendaki nilai maksimum atau nilai minimum bagi suatu graf fungsi kuadratik, maka pelajar boleh terus menggunakan formula $y=\frac{b^{2}-4 a c}{4 a}$.

\section{Kesimpulan}

Penguasaan kaedah penyempurnaan kuasa dua menunjukkan kelemahan dalam kalangan pelajar (Alhassan \& Agyei, 2020; Fachrudin et al., 2014). Kaedah tunjuk cara yang digunakan oleh guru memberi kesan kepada pencapaian pelajar, malah pengetahuan guru dalam fungsi dan persamaan algebra juga mempunyai hubungan terhadap prestasi pelajar (Maat \& Zakaria, 2014). Penggunaan formula adalah sebagai alternatif yang boleh digunakan oleh guru dalam membantu pelajar menyelesaikan persamaan kuadratik dan seterusnya menukar bentuk am fungsi kuadratik kepada bentuk verteks. Sesi bimbingan terancang pula memberi pengalaman yang menarik kepada pelajar untuk mendapat bimbingan peribadi daripada guru dan pelajar juga menunjukkan semangat yang tinggi. Sesi bimbingan ini sangat membantu guru dalam menganalisis kesalahan pelajar dan seterusnya membantu guru mengubahsuai kaedah pengajaran berdasarkan keupayaan pelajar. Dalam sesi temu bual, pelajar menunjukkan keraguan dan ketidakyakinan untuk menjawab ujian diagnostik. Ini berlaku kerana pelajar tidak biasa membuat latihan di rumah dan tiada bimbingan daripada rakan dan keluarga. Keyakinan meningkat apabila pelajar diberikan bimbingan dan ini terbukti dengan jawapan dalam latihan tambahan yang dijawab dengan betul oleh pelajar. Ujian penilaian juga memberikan dapatan yang positif yang mana menunjukkan semakin kerap pelajar membuat latihan, semakin meningkat prestasi pelajar. Pemerhatian yang positif ini membuktikan bahawa sesi bimbingan terancang boleh dilaksanakan dengan lebih kerap di sekolah untuk membantu meningkatkan pencapaian dan prestasi pelajar. Kajian seterusnya boleh dijalankan dengan melibatkan lebih ramai pelajar dengan pelbagai tahap pencapaian untuk membuktikan keberkesanan penggunaan formula verteks ini. 


\section{Rujukan}

Alhassan, M. N., \& Agyei, D. D. (2020). Colleges of education mathematics tutors' problems and challenges associated with the teaching of quadratics using completing the square approach. International Journal of Science and Research (IJSR), 9(2), 1842-1853. https://doi.org/10.21275/SR20212181653

Celik, A. O., \& Guzel, E. B. (2017). Revealing ozgur's thoughts of a quadratic function with a clinical interview: concepts and their underlying reasons. International Journal of Research in Education and Science, 3(1), 122-134.

Fachrudin, A. D., Putri, R. I. I., \& Darmawijoyo. (2014). Building students' understanding of quadratic equation concept using naïve geometry. Journal on Mathematics Education, 5(2), 192-202. https://doi.org/10.22342/jme.5.2.1502.191-202

Hendel, R. J. (2017). Are we meeting pedagogic requirements? - The quadratic equation. IMSCI 2017 11th International Multi-Conference on Society, Cybernetics and Informatics, Proceedings, 16(1), $185-190$.

Ling, C. Y., Osman, S., Daud, M. F., \& Hussin, W. N. W. (2019). Application of vee diagram as a problem-solving strategy in developing students' conceptual and procedural knowledge. International Journal of Innovative Technology and Exploring Engineering, 8(10), 2796-2800. https://doi.org/10.35940/ijitee.J9591.0881019

Maat, S. M., \& Zakaria, E. (2014). Analyzing pedagogical content knowledge of algebra using confirmatory factor analysis. Indian Journal of Science and Technology, 7(3), 249-253. https://citeseerx.ist.psu.edu/viewdoc/download?doi=10.1.1.919.2605\&rep=rep1\&type=pdf

Nielsen, L. E. J. (2015). Understanding quadratic functions and solving quadratic equations: an analysis of student thinking and reasoning. University of Washington.

Saundarajan, K., Osman, S., Daud, M. F., Abu, M. S., \& Pairan, M. R. (2020). Learning algebra using augmented reality. International Journal of Emerging Technologies in Learning, 15(16), 123-133. https://doi.org/10.3991/ijet.v15i16.10540 